\title{
Identity and the hybridity of modern finance: how a specifically modern concept of the self underlies the modern ownership of property, trusts and finance
}

\author{
Jongchul Kim *
}

\begin{abstract}
Postmodern thinker A. N. Whitehead argued that the idea of the identity of the self is one of the significant mistakes made by modern philosophy. From this postmodern perspective, this article examines how this mistaken concept underlies the modern ownership schemes of property, trusts and finance. It argues that exploiting the hybridity of money and credit explains the development of modern ownership from property to trusts and modern finance, and that, in the process of exploiting this hybridity, property owners struggle to endure and secure their identities permanently. This article also analyses unethical aspects of the hybridity of modern finance, as well as its systemic vulnerability, which contributed to the financial crisis of 2008. The essay concludes with a brief discussion of a general reform principle for the financial sector.
\end{abstract}

Key words: Postmodernism; Identity; Finance; Property; Trusts; Financial Crisis FEL classification: $\mathrm{G} 2$, E42, B52

\section{Introduction}

The ideas of identity and person are premises of modern Western philosophy. The modern philosophers Friedrich Hegel and John Locke explained the relationship between person and property. Critical legal theorist Roger Cotterrell (1987) explored how the legal relationship between person and property is extended to collective ownership and is made permanent by the legal institution of the trust. Legal theorist Frederic Maitland (1911) argued that this legal idea of the trust developed into the idea of the trust fund, which is prevalent in modern finance. John Maynard Keynes (1972) argued that the money motive of financial investors is a semi-pathological desire to secure 'a spurious and delusive immortality'. These scattered, fragmented insights can lead us to link modern ideas and institutions, such as the identity of the self, property, trusts, finance and the psychological desire for immortality. This linking helps us understand how the concept of modern ownership comes from the modern mind (especially that of a dominant group), which interprets and perceives itself and the

Manuscript received 3 April 2012; final version received 11 July 2013.

Address for correspondence: email: jongchul323@gmail.com

* Max Planck Institute for the Study of Societies, Paulstraße 3, Köln, 50676, Germany.

(C) The Author 2013. Published by Oxford University Press on behalf of the Cambridge Political Economy Society. All rights reserved. 
world in a peculiar manner. This understanding remains elusive, however, as long as these scattered insights remain fragmented because each of them by itself is limited. For example, Hegel and Locke assumed that the modern idea of person was a 'universal' concept, and even Cotterrell believed that conceptualissing a person as the owner of property is common sense $(1987, \mathrm{p} 83)$. Thus, these three theorists failed to realisse that the modern idea of personhood is a peculiar way of understanding the self and is ontologically problematic. Maitland did not develop his argument that the trust led to the trust fund in detail. Keynes understood the desire for immortality in a Freudian manner and never linked this desire with the mistaken modern idea of the identity of the self. This article attempts to overcome the limitations of these scattered insights and rethink the ontology of modern ownership.

Philosophers have debated the question of whether there is a persistent subject that undergoes change through time. Postmodern philosophers Alfred North Whitehead (1978, p 167) and Friedrich Nietzsche (1989, p 45) argued that this idea of personal identity is one of the significant mistakes made by modern philosophy. ${ }^{1}$ According to them, the idea comes from the false conception that reality has the same structure as language. Our language takes the form of 'subject and predicate'. When we think that reality has the same 'subject-predicate' structure as language, we separate the subject from the predicate, or the doer from the doing.

Based on the mistaken idea of identity, Hegel devised the concept of dialectics to explain how the various institutional forms of identity - such as money, the state and the world spirit-have developed. From a postmodern critical perspective, in contrast, this essay argues that rather than dialectics, the exploitation of the hybridity of money and credit explains the development of modern ownership from property to trusts and modern finance and that, in this process, property owners struggle to endure and secure their identities permanently.

As a result of this hybridity, the financial instruments of modern banking can be called credit-money. These instruments include bank notes, which are issued by commercial banks, and the shares of money market mutual funds (MMMFs) ${ }^{2}$ and repurchase agreements (repos), which have been issued by shadow-banking institutions in the twentieth and twenty-first centuries. ${ }^{3}$ Credit-money is self-contradictory because the concept of money is inherently contradictory to the concept of credit. The transfer of a credit instrument creates a creditor-debtor relation that imposes a repayment obligation on a debtor. In contrast, money, including cash issued by a central bank, is defined as anything that is generally acceptable in the final settlement of creditor-debtor relations.

The discussion of the ontology of modern finance must be founded on historical reality. We thus have to choose historical accounts that stimulate our new interpretation. The accounts that help us do so are those of Maitland (1911), Alan Macfarlane (1973), Ronald Stanley Neale (1975) and myself (Kim, 2011), which are critical of classical theories such as those of Karl Marx, Max Weber and Crawford Brough Macpherson, and which emphasise the central role of the trust in explaining the nature

\footnotetext{
${ }^{1}$ This article uses the term "postmodern" to include the twentieth-century philosophers who are sceptical of the modern conception of the self, for example, Friedrich Nietzsche, Alfred North Whitehead, Martin Heidegger, Gilles Deleuze and Michel Foucault.

${ }^{2}$ MMMFs are open-ended mutual funds that are registered under Rule 2a-7 of the Investment Company Act of 1940. MMMFs managed 24\% of U.S. businesses' short-term assets in 2006.

${ }_{3}$ Shadow banking refers to the bank-like financial activities conducted by unregulated or lightly regulated institutions outside of the traditional banking system.
} 
of modern ownership. For the discussion of shadow banking, this article also relies on the research of Gary Gorton and Andrew Metrick.

This article first examines the peculiar modern relationship between person and property. It then examines how this relationship is made permanent by both the trust and modern finance, which exploit a hybridity between person-property relationships and creditor-debtor relationships. Next, it examines how this hybridity has been exploited in shadow banking in the twentieth and twenty-first centuries. Finally, it comments on the moral implications of the idea of personality and modern banking in regard to forgiveness and briefly suggests as a general principle for financial reform the abolition of hybridity through the creation of a clear distinction between creditors' rights and owners' rights.

\section{Property and personality}

Richard Pipes (2000, pp 30-31) argues that in the first half of the seventeenth century in England, the term property was broadened to mean not only material objects but also the attributes of a person - including body and liberty. He further argues that this metamorphosis created the ideology of the 'birthright' of Englishmen to have property, liberty and freedom, and that this ideology had a direct political effect because Parliament used it in its struggle against the Crown.

The term property also has an ontological implication, because it pre-supposes an abstract concept of personhood. The two senses of property-attributes and thingstend to be conflated, which leads to two possibilities for conceptualising property. One is to treat all the attributes of a person, including labour, body and liberty, as things that the person can own and transfer to other persons. ${ }^{4}$ This is the 'property-isation' of the attributes of human beings. This property-isation pre-supposes the abstract person: after having turned all the attributes of a person into property owned by that person, what remains is the abstract subject that retains its identity as the owner of property. Through this process, as Cotterrell (1987) argues, the idea of property contributed to the generation of the modern ideology of human equality. Property - attributes and things - makes human beings different from each other. By considering human beings separately from their property, however, modern Western law treats them as the same and equal to each other. This is the concept of person in modern law.

The other possibility is to treat the right to possess things as 'natural'. The right to possess things is the same as the right to possess the natural attributes of human beings; therefore, this right exists prior to the establishment of social institutions or a consensus. This is the 'property-isation' of things. This property-isation formulates the abstract self as the possessor of a birthright to claim property. This is the modern ideology of human rights: human beings as persons are equally born with the right to possess property - understood as body, liberty and goods. To sum up, the modern ideology of property first separated human beings from their own attributes and the things they owned. This separation created the idea of the person in the abstract.

\footnotetext{
${ }^{4}$ This transferability is the reason natural rights theory was used for the justification of the slave trade. According to this theory, liberty is transferable: it can be sold, swapped, loaned or voluntarily surrendered. As David Graeber writes (2011, p 206), 'there could be nothing intrinsically wrong with, say, debt peonage, or even slavery. And this is exactly what natural-rights theorists came to assert. In fact, over the next centuries [beginning in the fifteenth century], these ideas came to be developed above all in Antwerp and Lisbon, cities at the very center of the emerging slave trade'.
} 
It then reformulated the person as the 'owner' of property, who has a natural right to claim property.

These two property-isations occurred in Locke's idea of property, which provided the ideological foundation for the Glorious Revolution. He argued that 'By Property I . . . mean that Property which men have in their Persons as well as Goods . . . life, liberty and estates' (1690 [1988], \$173). Here, by turning all the attributes of human beings into property, Locke's idea of property pre-supposes the abstract idea of personhood. For Locke, property did not originate through a social consensus, but instead was the birthright of free men in the state of nature. When a person adds this property-labour - to Nature, Locke argued, that part of Nature becomes his property. This is the property-isation of things. ${ }^{5}$

The postmodernist insight that there is no abstract subject that undergoes change and endures through time implies that it is futile for the self to be attached to its endurance. Whitehead argued that enduring personal identity is merely the abstract derived from the shared characteristics of actual entities, and this abstraction is mistakenly made the subject by modern philosophy. He also criticised the belief in the endurance of the self, arguing instead that the subject or the self does not endure. According to Whitehead, the self is created and destroyed at once and is without temporal endurance, and all things in the universe participate in this creation. This is a conception of the eternal present and refers us to Buddhist practices, which cause us to be conscious of the enjoyable completeness of the eternal present in whose creation the universe participates. According to the Buddhist idea of emptiness and Whitehead's philosophy, no existence has an enduring subjectivity. In Buddhism, having an enduring personal identity is the result of karma, which individuals' ignorant behaviour has brought about, and which a Buddhist tries to overcome.

The two property-isations, which establish the relationship between the abstract person and property, set the stage for the modern project of making personal identity endure permanently. The next sections of this article examine how the trust and modern finance are the means for this project. Keynes would call this project the semipathological desire to secure immortality (1972, p 32).

\section{Trusts and personality}

Roman law strictly divided 'rights in rem' from 'rights in personam' and considered any mixture of these two rights to be a crime. Interestingly, the trust arose out of the violation of this Roman legal principle. The trust is, by definition, a hybrid between rights in rem and rights in personam (Maitland, 1911). It is an English legal concept that distinguishes the English common law from the Roman law tradition of continental Europe. Due to its hybridity, the trust establishes a double ownership that makes it possible for two exclusive ownership claims to exist simultaneously over the same asset-legal ownership claimed by trustees, and equitable ownership claimed by beneficiaries.

${ }^{5}$ Similarly, for Hegel, at the first stage of historical evolution the self begins as an abstract single person (1962, \$35). As in Locke's theory of personhood, this abstraction of personhood is possible because Hegel property-ised the attributes of a person. For Hegel, property includes not only external things outside a person, but also things inside a person, such as his or her productive capacity and body, and thus a laborer is a property owner because he or she has property in his or her productive capacity, and that property can be alienated. 
Most of the major institutions of capitalist society are trusts. Representative democracy is a trust, as Locke demonstrated. Joint stock arrangements with limited liability in business corporations are a trust. Even imperial powers used the idea of the trust by considering themselves to be the 'trustees' of their colonies. Let us examine how the trust makes the Lockean formula of person-property endure permanently.

The trust is an extreme case of the permanent extension of personal identity by making the individualist purposes of property owners endure even beyond a life span. Since the early thirteenth century, the landed class had used the trust-and its feudal form, the use of land - as a device to make its interest in property endure when endurance was impossible, for example, after death or due to external interference. The use had been exploited for various reasons, for example, because an individual wanted 'to escape from his creditors; or feared that a conviction for felony would result in the loss' of his or her property and lands (Martin, 2001, p 8). However, the most important external force that the exploitation of trust or use tried to escape was feudal duties and taxation by the rulers or the state. Even today, tax avoidance is a dominant motive for the creation of trusts (Martin, 2001, p 43). To avoid all the legal responsibilities of an owner, the owner transfers legal ownership to a group of replaceable trustees but retains equitable ownership. The replaceable group solves the problem of an individual trustee whose death can terminate a trusted interest. The particular members of the group at any given time merely represent the will of the settler and are obligated to promote that will permanently.

It was the rich and powerful who used the trust. The motivation that led to their invention of the use was, as Sir Edward Coke described in 1594, 'fear and fraud: fear in times of troubles and civil wars to save their inheritances from being forfeited; and fraud to defeat due debts, lawful actions, wards, escheats, mortmains, etc. ${ }^{6}$ This fear regarding inheritance was unjustifiable according to the feudal principle of land tenure because the contract was made between two individuals - a lord and a tenant-not between a lord and a tenant family (Macfarlane, 2002, pp 59-72). The inheritance of land was justified only when the duties and services of a tenant were also transferred. But the trust was intended to make it possible to avoid these duties and service whilst allowing the individualist purposes of property owners to endure.

If the trust makes it possible for personal identity to endure permanently, it also overcomes the limited life span of property. Because things can decay or be destroyed, the endurance of the person-property relationship is limited. But the trust fund 'makes possible the creation of enduring objects of property ... in the form of funds which can be invested in various ways to preserve and enhance their value' (Cotterrell, 1987, p. 85). In the trust fund, therefore, the particular assets that are owned at any given time merely represent the abstract value that the trust intends to preserve and enhance. To sum up, in the trust fund, the formula of person-property becomes more abstract: it becomes the relationship between the person in the abstract, established in the form of replaceable trustees who promote the will of the settler, and things in the abstract, where an investment in particular assets is intended to promote the abstract value of the fund (Figure 1).

This formula explains the co-existence of the two seemingly contradictory forms of property in capitalism: absolute private property and divisible property rights to future income. Macpherson (1975) interpreted Locke's labour theory of property

${ }^{6}$ Chudleigh's case (1594) 1 Co Rep $113 \mathrm{~b}$ at $121 \mathrm{~b}$. 


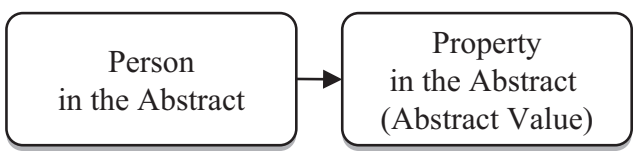

Fig. 1. The person-property formula in the trust

as an ideological justification for the exclusive, alienable form of property-absolute private property. He and other classical writers, including Marx and Weber, all argued that the nature of the transition from feudalism to capitalism can be understood as the rise of absolute private property. Challenging this classical argument, revisionists such as Gerry Rubin and David Sugarman (1984, pp 34-35) and Neale (1975) argued that the classical argument tends to de-emphasise the other capitalist form of property. They demonstrated that during the transition to capitalism, the divisibility of property titles and legal titles to present and future income-such as shares, mortgages and pensions - were treated as property by the law of trusts in England. They pointed out that without this form of property, absolute private property alone could not have made the transition possible. Responding to this challenge, Macpherson (1975, p 114) mistakenly argued that this form of property developed later, in the welfare capitalism of the twentieth century, and replaced the absolute private property developed in early laissez-faire capitalism. For Macpherson and the other classical writers, these two forms of property are considered to be essentially different and perhaps even contradictory.

However, our formula demonstrates that the Lockean formula of person-property that justifies absolute private property is included and extended in the person-property formula of the trust. The trust originated from the principle that individuals have the absolute freedom to transfer their property as they please without consideration of the will of their family or inheritors (Langbein, 1997, p 184). To make their absolute property ownership endure permanently - that is, to make the person-property formula endure permanently - property owners devised the trust, in which the relationship between the owners and the group of replaceable trustees is a hybrid between an owner-representative relationship and a creditor-debtor relationship. Investors transfer their legal ownership of funds to the trust company to secure the funds from their creditors or government taxation, or to maintain the value of the funds. Without this transfer of legal ownership, the company cannot invest the investors' money in its own name. In return for the investors' transfer of legal ownership to the company, the trust company pays an interest-like benefit-dividends - to the investors. So far, because legal ownership has been transferred from the investors to the company, the relationship between the investors and the company is a creditor-debtor relationship. But at the same time, the investors retain equitable ownership, as a result of which the company is obliged to work for the best interest of the investors, and thus ownership is not transferred to the company. Here, the relationship between the investors and the trust company is an owner-representative relationship. Two economic transactionsa loan transaction and a money transaction - which had been clearly distinguished before modern times in Roman law become mixed in the trust. The shareholders of the trust are no longer the owners of the specific funds they invested, but of part of the company's pool of funds, and they have a right to claim the expected future earnings of the trust. When the value of their shares drops, the shareholders can withdraw quickly from the trust by selling their shares to third parties or liquidating them on 
demand. Here, the motive of securing private property rights in the Lockean formula is enhanced, and the two property forms - absolute private property and divisible property rights to future income-are combined. Because the trust played a central role in bringing about the transition from feudalism to capitalism (Neale, 1975), contrary to Macpherson's argument, there was no historical transition between the two in the twentieth century.

The trust is largely absent in Marx's, Weber's and Macpherson's writings on the origin and nature of capitalism. However, Maitland's (1911), Neale's (1975) and Kim (2011)'s research demonstrates the central role of the trust in the origin and nature of capitalism.

Maitland (1911) argued that the transition from feudalism to capitalism was not so much 'from status to contract' as 'from contract to trusts'. He argued that the essence of capitalism cannot be explained through the concept of the contract but through a specific form of ownership and collective-the trust (1911, p 314). He argued that the effects of the trust extend across the economy and politics, from the creation of joint stock arrangements with limited liability to the imperial idea of trusteeship.

Neale also criticised the classical theory of the transition from feudalism to capitalism for overemphasising the central role of market forces and their agents, the bourgeoisie. He argued that the class of landowners and their ideology-especially the trust - provided the legal and institutional framework 'which alone made possible the development of industrial capitalism in England' and that the bourgeoisie of the eighteenth century merely borrowed the trust almost intact (1975, pp 95-101).

Like Neale's, Kim's historical account (2011) refutes the classical theory that modern banking arose because the development of the market demanded more means of payment. Instead, he demonstrates that it originated from the politics and morality of the trust that underlay the political struggle between the Crown and landowners in England. He argues that modern money is a trust: like the double ownership of trustees and beneficiaries in the trust, in modern banking two groups - the holders of bankers' notes and depositors - are the exclusive owners of one and the same cash that is kept in bankers' vaults, and one amount of cash creates two cash balances of the same amount, one for the holders and the other for depositors. This, he argues, is a mechanism for the creation of money out of thin air.

\section{Modern banking and personality}

\subsection{The distance between person and property in modern banking}

Let us continue to examine how the person-property formula of the trust developed in modern banking. In the trust, property owners first transfer the legal ownership of property to trustees. This is the separation between person and property. At the same time, the beneficiaries of the trust maintain their equitable claim. This is the connection between person and property.

In modern banking, as in the trust, person and property are both separated and connected. Modern banking grew from traditional deposit transactions that provided safekeeping services to depositors. The epoch-making innovation that founded modern banking occurred when some ingenious goldsmith-bankers issued additional deposit receipts to those who came to borrow from them (Kim, 2011). Figure 2 describes 
(a) Regular Deposit (Non-fungible Thing)

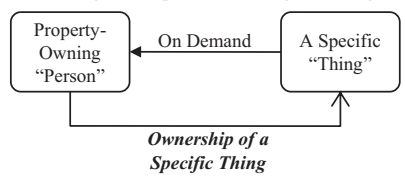

(b) Irregular Deposit (Fungible Thing)

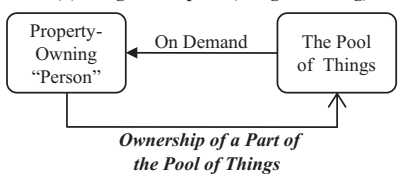

(c) Modern Deposit Banking

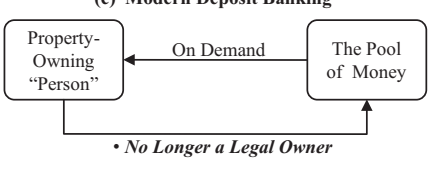

Fig. 2. Separation between person and things

different degrees of separation between person and property in three deposit transactions. In traditional regular and irregular deposit transactions-Panels a and $b,{ }^{7}$ respectively - a specific depositor maintained ownership of a specific property or of a part of the pool of property, whereby there was no separation between person and property. Traditional deposit transactions were primarily intended to keep property safe. Depositaries charged depositors a safekeeping fee. There was a long moral and legal debate as to whether depositaries' attempts to utilise deposited funds for their own profit constituted a crime. This mixture of loan making and deposit taking was considered embezzlement under the above-mentioned Roman principle (Huerta de Soto, 2009). For example, in Catalonia in 1360, a banker who failed to return deposits to depositors was beheaded in accordance with the law (Huerta de Soto, 2009, p 76). The continental public deposit banks were strictly forbidden to loan deposited funds to private individuals (de Roover, 1974, 228).

In modern banking (panel c), however, there is a separation between person and property, but the connection between the two was nonetheless maintained. This separation and connection can co-exist because modern deposit banking is, like the trust, a hybrid between rights in rem and rights in personam or between a deposit transaction and a loan transaction. In a deposit transaction, as in Figure $2 \mathrm{~b}$ and $\mathrm{c}$, the rights of a depositor are rights in rem,' rights against a thing, because the demand clause of bank notes allows their holder to withdraw the funds deposited in the banks' vaults at any time on demand, and thus the holder practically retains ownership of the funds. Therefore, as long as modern banking is a deposit transaction, there is no separation between person and property. But modern banking is also a loan transaction, in which the rights of a depositor are rights against a person, rights in personam. The depositor cedes legal ownership of property to a depositary and, in exchange, obtains a debt claim that goes against a person. The depositor can oblige the depositary to fulfil an obligation to repay the principal and interest. But the depositor is not concerned with how the depositary uses the deposited funds and does not bear any responsibility for the results of their use. As a loan transaction, modern banking maintains the separation between person and property.

\subsection{The abstraction of person and property in modern banking}

Like the trust, modern banking presupposes the abstractions of person and property. Goldsmiths' bank notes began to use a 'bearer clause' (payable to a bearer) and, by doing so, effectively contracted with 'an anonymous person in the community' who held the bankers' notes. That is, the bankers were not really concerned with who was the specific holder of the notes, because a change in the holder did not change the bankers' obligation. As illustrated in Figure 3, the contract counterpart of the bankers,

\footnotetext{
${ }^{7}$ Regular deposits are heterogeneous and thus distinctive things, and irregular deposits are fungible things, like money and grain.
} 


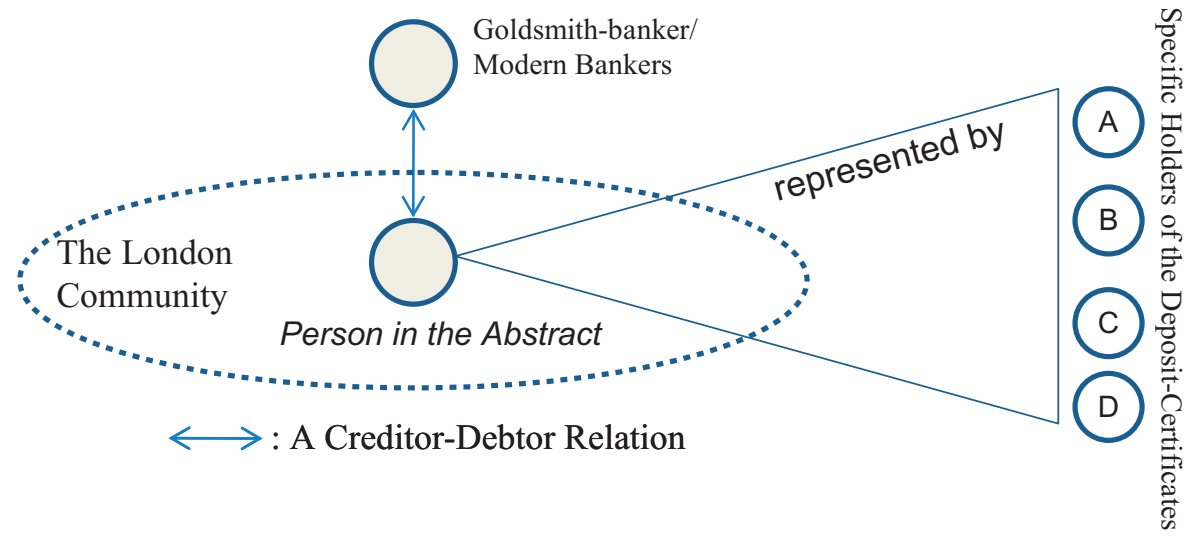

Fig. 3. Property owner as 'person in the abstract' in modern banking

from the standpoint of the bankers, was not a specific person $\mathrm{A}, \mathrm{B}, \mathrm{C}$ or $\mathrm{D}$ but the abstract person that existed during the whole period of transfers from $\mathrm{A}$ to $\mathrm{B}$, from $\mathrm{B}$ to $\mathrm{C}$ and from $\mathrm{C}$ to $\mathrm{D}$. This abstract person was represented by the specific holders$\mathrm{A}, \mathrm{B}, \mathrm{C}$ and $\mathrm{D}$.

To use a bearer clause in their notes, the bankers needed to treat all holders equally. Thus, as the economic historians Hans-Joachim Temin and Peter Voth have demonstrated, for modern banking to have developed, the idea of the equality of persons already had to have been developed:

Aristocrats ... were recorded sequentially with other loans. Aristocrats may possibly have had easier access to credit in general, but they did not get segregated into a separate account. London had become sufficiently egalitarian by 1700 for aristocrat and commoner to use the same bank in the same way. (Temin and Voth, 2006, pp 169-70)

The equality of all free men before the law has been a central tenet of English law since at least the thirteenth century (Maitland, 1911; Macfarlane, 1973, p 44). Here we can say that modern banking is the outgrowth, rather than the cause, of the modern ideology of human equality that the formula of person-property generates. ${ }^{8}$

Modern bankers loan deposit funds to industrialists and merchants in the name and at the discretion of the bankers. In turn, the borrowers invest the funds in various forms of property. The investment is only instrumentally concerned with a specific form of property; ultimately, it is concerned only with an increase in the abstract value of the property. What the bankers expect from the borrowers is simply the return of the monetary principal with interest. Thus, in modern banking, the relationship between person and property is a relationship between personhood in the abstract and property in the abstract (see Panel $b$ in Figure 4).

These abstractions occur because modern deposit banking is a trust, a hybrid of a deposit transaction and a loan transaction, that is, because it maintains a fractional reserve. The bearer clause of deposit certificates was not suited to deposit services that required $100 \%$ reserves, because the depositary would not know who the current holders of the certificates were, and as a result, the depositary would hardly collect any

\footnotetext{
${ }^{8}$ But modern banking also reinforces the movement towards equality, which was far from complete in the thirteenth century.
} 
(a) Concrete Property Rights

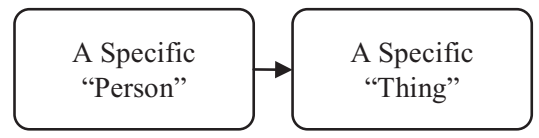

(b) Abstract Property Rights

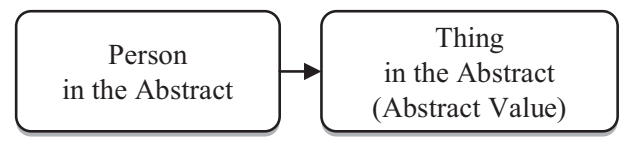

Fig. 4. Two distinctive forms of property rights

storage fees, which were his main source of profit (White, 2003, p 425). It seems that in Western history, deposit certificates did not circulate freely outside the circle of depositors of an issuing bank until goldsmith-bankers began to use fractional reserve deposit banking and transferable notes payable to the bearer. Thus, in a deposit transaction with a full reserve ratio, unlike in modern banking, the ownership relationship between person and property was close to Panel a in Figure 4.

A bearer clause is also less well suited to credit instruments such as bills of exchange. Bills of exchange began to be used widely by merchants on the European continent beginning in the late Middle Ages. However, the assignment of bills of exchange developed away from the early use of a bearer clause and towards the establishment of the rule of endorsement with an order clause (payable to ' $\mathrm{X}$ or order'), because bills of exchange with a bearer clause were troubled with negotiability. As the bills were transferred between merchants, they were necessarily removed further from the original debtor, the drawer of the bills. For the bills to be transferable without having their value diminish, their transferees should possess at least the same degree of confidence in the original debtor as their transferors. However, it was nearly impossible to meet this requirement because of the growing distance between transferees and original debtors. To solve this problem, merchant custom developed the rule of endorsements 'A or order', by which the transferors of bills of exchange were added to the liable parties (Quinn, 2004, p 154). Furthermore, because merchants usually transferred bills of exchange to a merchant to whom they were previously indebted, and by doing so wanted to cancel their previous debt, the bills were not transferred freely outside the network of merchants. Thus, unlike bankers' notes, the bills were not intended to contract with an anonymous person in the community who held the bills. Therefore, there was no abstraction of the person in the transaction of bills of exchange.

\subsection{Why did the distance and abstraction develop? Fungibility or hybridity}

Why did the distance and abstraction develop? Theorists have argued that they developed due to the fungibility or homogeneity of money. For example, Georg Simmel argued that person and property are separated so that shareholders in a joint stock company can exert ownership control without possessing the company's assets directly. This separation occurs, Simmel argued, because the money that mediates shareholders' investment is abstract. This abstract money is homogeneous and free from all qualities and can thus be an equivalent for everything (Simmel 1896 [1991], p 24).

However, this idea of identity, according to which money is an abstract equivalent, seems to be peculiar to the modern mind. As Graeber (2011, pp 133-36, 158) argues, before modern times, in societies where money was not yet used for the exchange of commodities, money symbolised the impossibility of identity. For example, in the Six Nations of the Iroquois, when murder occurred, wampum was paid for reconciliation, but the payment did not imply that the value of wampum represented the value of the 
dead man's life; rather, it implied the impossibility of identity. Coins created by emperors were exchanged for goods not because the coins had the same value as the goods but because they were stamped with the sacred image of a god or king. The value of the coins was usually higher than the value of their metal content.

However, the value theories of classical economists invented the abstract-for example, labour for David Ricardo. Their theories mimic Newtonian physics (Mirowski, 1989). In the Newtonian notion of substance, the ultimate being of nature is considered to be 'continuous stuff with permanent attributes, enduring without differentiation, and retaining its self-identity through any stretch of time however small or large' (Whitehead, 1978, p 78). This notion of substance allows Newtonian scientific materialism to presuppose that natural beings are traditional geometrical entities, all of whose essential facts are reducible to a simple physical quantity. Whitehead (1978) criticised this idea of identity by examining how modern physics, such as Einstein's theory of relativity and quantum physics, revises the Newtonian idea of matter. From this Whiteheadian postmodern perspective, the search for the abstract or substance and the attempt to reduce quality to quantity in economics are in vain.

Contrary to Simmel's belief, fungibility or homogeneity cannot cause the separation between person and property, at least in the case of modern banking. In England around the late sixteenth and early seventeenth centuries, fungibility was often used in common law courts to characterise the deposit taking of money as a loan transaction, in which ownership was transferred to debtors and thus separated from owners, and, by doing so, to justify depositaries' personal use of deposited funds. This argument was made, for example, in Bretton v. Barnet (1598) and Higgs v. Holiday (1600). However, fungibility was no longer used in Foley $v$. Hill and Others (1848), when common law courts finally settled the issue of bank deposits as loans to banks. ${ }^{9}$ In that case, Lord Cottenham did not explain why fungibility was no longer used. But we can easily reason it out: the fungibility of money explains the depositary's right to mix the deposited money but does not necessarily justify the depositary's right to use the money.

When Simmel said that the distance between a shareholder and property in joint stock companies occurs, he failed to identify that this distance occurs due to the hybrid, double ownership scheme. That is, long-distance ownership occurs because investors cede their legal ownership of funds to a company but at the same time retain equitable ownership to control the company (see Simmel, 1896 [1991], pp 9-10). Through this hybrid, owners can earn income and control business without direct involvement and responsibility.

We no longer grant money the transformational power of generating the distance and abstraction of the person-property formula. Rather, the distance and abstraction were caused by the changed ideas, morality and institutions that led modern banking to exploit the hybridity between deposit transactions and loan transactions, and this hybridity makes the formula of person-property endure permanently. To express this hybridity in Hegelian style, to endure permanently the relationship of person-property appropriates its opposite, the creditor-debtor relationship, as its element. However, this process differs essentially from Hegelian dialectics, because Hegel presupposed the abstract self. In his dialectics, the abstract self appropriates its opposite, the concrete, as its moment and, by doing so, develops into a universal, concrete form of the self.

9 2. H.L.C.: $36-37$. 
Kim (2011) examines how this hybridity of modern banking originated in early modern England. It came about because property owners struggled against the Crown to make their interest in property endure longer. The historical event that led to the goldsmiths' invention was Charles I's appropriation of cash deposited in the London Mint. In 1638, to raise funds for a war, Charles I appropriated $£ 200,000$ in coin and bullion deposited by London merchants in the Mint. Even though the Crown returned the sum on the condition that the depositors loan him $£ 40,000$, property owners sought alternatives. A number of London goldsmiths offered an alternative safekeeping service by using the trick of hybridity. They printed additional deposit certificates and loaned them to numerous third parties whilst still offering depositors the right of withdrawal on demand. This use of loans for safekeeping was not unique in history. Around the middle of the seventeenth century, bankers in Seville loaned most deposited money to private industry and commerce to escape Charles V's attempt to confiscate the funds remaining in their vaults (Huerta de Soto, 2009, p 79). But goldsmith-bankers were more innovative: instead of emptying their vaults, they introduced transferable bank notes. This introduction was very successful in 'merging' the interests of numerous third parties in the same funds. Creating simultaneous ownership interests by third parties and depositors would make it harder for the Crown to appropriate the funds and elicit greater opposition if it actually did so.

The other cause for its origin, according to Kim (2011), was that hybridity provided depositors and depositaries with new benefits that they could not enjoy from either deposit transactions or loan transactions alone. In a deposit transaction, depositors are required to pay a safekeeping fee; in a loan transaction, creditors cede the present availability of funds to debtors for a fixed term. But in goldsmith-banking, depositors were paid interest and withdrew their money at any time on demand. Furthermore, goldsmith-bankers could collect huge deposits because they offered an interest payment and the promise to repay deposits at any time on demand. Then they created additional deposit certificates and loaned them to third parties for personal gain. These huge deposits and additional deposit certificates made them the biggest debtors in England. Because their debtors would not all withdraw their money simultaneously, a portion of the debts remained in the hands of the bankers and was transformed into permanent capital, which the bankers used for profitable long-term investment. For example, prominent goldsmith-bankers, such as Alderman Blackwell, earned record profits at that time from their investment in the Crown. Long-term investment in the Crown was the only exception to the usury law, which prohibited interest rates above $5 \%$ or $6 \%$ : the prominent bankers charged an interest rate of $10 \%$ or more on loans to the Crown. This is the story of the birth of the modern big debtor.

There was legal resistance to the origin of modern banking. Chief Justice Holt in the cases of Clerke v. Martin (1702) and Buller v. Crips (1703) objected to treating the goldsmith-bankers' notes under the same rules as bills of exchange. According to James Rogers, there was ample reason for Holt's decisions. Common law courts had adopted the custom of merchants into the common law beginning in the early seventeenth century and had shortened and simplified pleadings for actions on bills of exchange. A main reason for these changes was that the courts regarded bills of exchange as more than mere loan transactions. The bills were intended for trade and were thus called bills of exchange. Thus, the court had made a distinction between the special commercial rules governing bills of exchange and the general principles of debt obligations. If this distinction were not made, a creditor would be able to bring 
an action under the special commercial rules even if the case was merely about a loan transaction, and this possibility would unfairly benefit the creditor (Rogers, 1995, p 183). For Holt, goldsmith-bankers' notes were mere loan transactions; they did not develop from merchant custom, and thus could not be treated in the same manner as bills of exchange. Rogers concludes that Holt's rulings were 'an effort, albeit unsuccessful, to deal with the inherent problem of defining the limits of commercial laws' (1995, p 186).

The ethics of the hybridity of modern banking has been contested. The Austrian school of economics (Huerta de Soto, 2009) argues that modern banking commits two frauds: one is embezzlement by a bank against its depositors, and the other is fraud by a bank and its depositors against third parties. Historical research on the origin of modern banking by Kim (2011) rejects the claim that the first supposed fraud actually is fraud. Even though banks' loaning of deposited funds could be considered embezzlement according to the Roman law principle, he argues, goldsmith-bankers loaned deposits to third parties with the explicit or implicit permission of their depositors. But he admits that the second fraud occurs because a bank and its depositors have in fact contracted to create additional titles and claims to the same quantity of property when the depositors allow the bank to loan their deposits to third parties. This creation is a fraud because no one can loan what she or he does not have (Huerta de Soto, 2009). Furthermore, this creation of a hybrid - credit-money - exposes a community to a new type of risk that did not exist in the traditional safekeeping business: the risk of illiquidity in the form of bank runs and other types of liquidity crunches. This risk is like the risk in a 'pass the parcel' game, in which 'the loser is the one holding the parcel when the music stops' (Horsefield, 1977, pp 124-25). The historical innovation of modern bankers' transferable paper money contributed to the widespread circulation of this fraudulent creation within a community. Earlier deposit bankers loaned deposited funds mainly in the form of overdrafts that a depositor would use to settle a payment with other depositors. That is, in the system of book transfers, the additional titles and claims that the bankers created were not offered to third parties outside the circle of depositors and clients. In contrast, modern bank notes payable to bearer are transferred from hand to hand between anybody in a community and thus introduce a wide range of third parties. When depositors suddenly realise that the banks' loaning of the money to third parties is in trouble, they create a run on the banks so as not to be the loser. Then when modern banking creates economic recessions, it generates high costs for third parties who are innocently involved in the transactions of bankers' paper money-including workers, suppliers, consumers and peripheral countries (Huerta de Soto, 2009). Developed countries have devised various means of maintaining this vulnerable, fraudulent modern banking system-especially the establishment of the central bank as the lender of last resort to banks and the establishment of deposit insurance (Huerta de Soto, 2009).

\section{The hybridity of shadow banking}

Before the financial crisis of 2008, various forms of trust schemes were used widely by big debtors in a new shadow banking system - for example, by MMMFs and repo markets. Gorton and Metrick (2010) argue that the three key elements of shadow banking-MMMFs, securitisation and repos-played a central role in the crisis of 2008. Investors' runs on MMMFs (and other institutional funds) and these funds' 
runs on repo markets generated the crisis of 2008. These runs and the resultant financial crisis occurred, Gorton and Metrick demonstrate, because those key elements utilised the hybrids of money and debt, that is, money-like debt instruments such as repos and MMMFs' shares. As a result, the crisis was 'structurally similar to centuries of previous panics involving money-like instruments such as bank-notes and demand deposits' (2010, p 280).

Let us discuss how shadow banking exploits the same hybridity as traditional banking. Figure 5 illustrates (despite some danger of over-simplification) a simplified mechanism of off-balance-sheet financing. Traditional commercial banks supply securitised financial products to the shadow-banking system, where dealer (investment) banks develop a repo market to broker those securitised products to MMMFs and other intuitional funds that invest in those securitised products or in the repo market.

In the previous section, we examined point 1 of Figure 5-the traditional banking relationship between commercial banks, depositors and borrowers. In the twentieth and twenty-first centuries, in point 2 of Figure 5, banks no longer hold within their balance sheets the portfolios of the loans they made to borrowers. Instead, they transfer the pool of loans-including mortgage debts, credit card debts and automobile debts - to a trust company (a special-purpose conduit), and this trust company slices the pool of debts into different tranches, which it then sells to investors. These products are called asset-backed securities and collateralised debt obligations (CDOs). Those conduits raise funds by selling short-term asset-backed commercial papers (ABCPs). These safe ABCPs are insured a AAA-rating and sold primarily to MMMFs. The sale of these products is usually brokered by investment banks such as Merrill Lynch and Morgan Stanley.

Before the 2008 crisis, off-balance-sheet financing looked safe from the standpoint of investors. If the conduits went into default, the owners of ABCPs could seize and sell the underlying collateral assets because ABCPs were backed by a pool of mortgages or other debt obligations. To prevent a default, large banks typically provided credit guarantees to their conduits. CDOs sold and purchased in repo markets were mainly the safest tranches. Because the purchasers of these tranches usually bought a credit default swap (CDS), an insurance contract, to protect themselves, AAA-rated tranches with CDSs were reasonably regarded as safe assets with almost no risk of default. The toxic waste- the most junior tranche of sub-prime mortgage loans - was often held by the issuing bank and was thus rarely injected into our off-balance-sheet financing picture. But investors created a run on MMMFs, and these funds suddenly created a run on the repo market. The reason for these runs cannot be explained entirely by

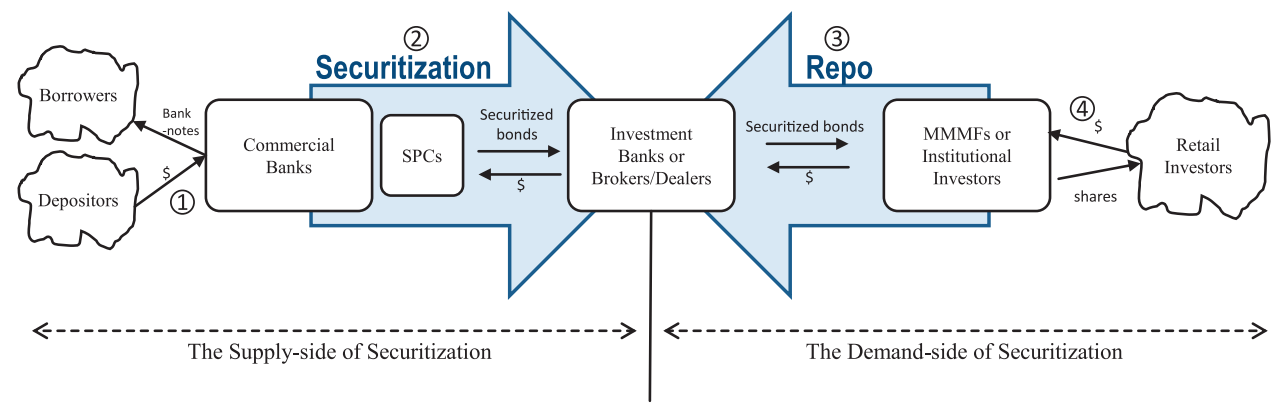

Fig. 5. Off-balance sheet financing 
the sub-prime mortgage crisis because 'prospective subprime losses were clearly not large enough on their own to account for the magnitude of the crisis', as Ben Bernanke claimed (quoted in Financial Crisis Inquiry Commission [FCIC], 2011, p 27).

As Kim (2011) argued, the traditional relationship between banks, depositors and borrowers (1 of Figure 5) establishes a hybrid, double ownership scheme-a moneycreation mechanism - and this creation of two exclusive owners over the same amount of money is a fundamental cause of bank runs and liquidity crunches. This is still true whether or not banks hold the portfolios of the loans they made to the borrowers on their balance sheets. The same mechanism of hybridity is found in point 4 of Figure 5 . Most institutional funds are open-ended, making it possible for their retail investors to liquidate shares on demand (Stein, 2005). In particular, in 1977 Merrill Lynch for the first time offered its MMMF shareholders something even more like a demand deposit account; it offered them 'cash management accounts', which allow these shareholders to write checks (FCIC, 2011, p 30). This open-endedness creates a double ownership structure in which two exclusive owners - shareholders and the institutional fundsenjoy the present availability of the same amount of funds. Because retail investors can withdraw the funds invested in the pool of MMMFs or other institutional investors at any time on demand, they retain the present availability and ownership of the funds. The shareholders can use their shares as collateral for loans or to write checks. But at the same time, MMMFs and other institutional investors lend the funds in their own names, attaining and retaining the ownership title of the loan. The ownership of the funds is thus transferred from retail investors to institutional investors. Here, the ownership of the funds is transferred and not transferred. Securitised bonds in point 1 of Figure 5 are, as we saw earlier, the money created out of thin air by commercial banks through a double ownership scheme. Similarly, in shadow banking, the money invested by MMMFs and other institutional investors to buy securitised bonds is also created out of thin air through a double ownership scheme. This money absorbed enormous amounts of capital and resources from abroad for a decade, which was used to support the US housing boom and other forms of mass consumption.

Unlike other mutual funds, MMMFs have been exempted by the Security and Exchange Commission's (SEC) Rule 2a-7 from mark to market, so that MMMFs do not adjust their prices per share to reflect the daily market value of their assets. Thus, MMMFs can claim their assets are always worth 100 cents on the dollar, even when they are not. By promising to maintain a net asset value of $\$ 1$ per share, together with the openendedness of the shares, MMMFs falsely lead their shareholders to believe that what they have kept in MMMFs is cash. This is the same false belief that the depositors in demand deposit accounts possess in traditional banking. When the shareholders suddenly realise that their belief is wrong, they create a run on MMMFs. On 16 September 2008, when the Reserve Primary Fund - a large MMMF with $\$ 65$ billion in assets - announced that its shares were worth only 97 cents, it faced about $\$ 39.6$ billion in redemption requests (Kacperczyk and Schnabl, 2010, p 41). This event further triggered bank runs on other MMMFs and resulted in the withdrawal of about $\$ 172$ billion in a week (Kacperczyk and Schnabl, 2010, p 41). MMMFs were thus forced to sell their assets, especially commercial paper, at fire-sale prices, creating a major liquidity crisis among the prime borrowers in the commercial paper market, of which MMMFs own approximately 40\% (Musto, 2011, $\mathrm{p}$ 164). Such runs would have been much greater, and the US financial system would have collapsed, had the US Department of the Treasury not promised temporary deposit insurance covering the entire $\$ 3.45$ trillion worth of MMMFs on 19 September. 
Gordon and Metrick (2010, p 279) argue that a run on repos was also the core problem in the crisis of 2008. Even though there are no official data, the US repo market exceeded $\$ 10$ trillion in mid-2008. Mutual funds, including MMMFs, are important investors in the repo market.

Repo markets boom and collapse because repos are a hybrid scheme between money and debt. Sales and loans are distinct transactions. Sales are money transactions in which the payment obligations of buyers are finally cleared; in contrast, loan contracts impose payment obligations on debtors. Repo contracts are a hybrid between loans and sales. A repo is in its economic substance a secured loan in which a creditor receives securities as collateral to protect him- or herself against the default of a debtor. In point 3 of Figure 5, MMMFs or other institutional investors buy a repo contract at the price of $\$ \mathrm{X}$ and receive some asset from an investment bank as collateral; the bank agrees to repurchase the same asset in the future for a higher price of $\$ Y$. The percentage $(\mathrm{Y}-\mathrm{X}) / \mathrm{X}$ is called the repo rate and is analogous to the interest rate on a secured loan.

However, a repo legally takes the form of a sale contract. Because a repo is disguised as a sale contract, it has two advantages over a loan contract. First, a repo is treated differently from a loan contract when a party goes bankrupt. A loan contract is subject to the Chapter 11 bankruptcy process, and thus when a debtor goes bankrupt, a creditor must stay automatically - that is, he or she is prevented from selling the collateral without court permission. A repo is, however, excluded from Chapter 11 and is thus not subject to the automatic stay, because a repo contract is treated as a sale by the courts. If one party to a repo transaction goes bankrupt, the other party can unilaterally terminate the transaction and keep the cash or sell the collateral. Furthermore, overnight repos (which mature in one day) have become increasingly prevalent since 2003 and had doubled by 2007. Overnight repos allow institutional investors to withdraw their investments daily. Thus, both overnight repos and the exemption from the bankruptcy process make the creditors of repos similar to depositors who write a check from their bank accounts and withdraw money on demand at any time.

Second, in a secured loan contract, the ownership of collateral is not transferred to a creditor; in a repo, the transfer occurs because it is a sale contract. Thus, the creditor further pledges and uses the collateral. A single piece of collateral is often used to effect settlement in a number of contracts on the same day. A double ownership is established here, as in commercial banks' demand deposits. The selling price of the collateral is, as mentioned, the amount of the loan that is delivered to the debtor of a repo. The debtor enjoys its ownership and uses its present availability. But at the same time, its creditor takes the ownership of the collateral and uses it for other contracts. It is money creation because the creditor does not loan any money to a debtor from the perspective of the creditor, even though the debtor uses the money. Those two benefits make it possible for investors to create a run on repo markets. When investors feel that a firm might go bankrupt, they create a run on the firm, withdraw investment, and drive the firm into bankruptcy. Such a run happened to Bear Stearns in 2007 and to Lehman Brothers, causing the financial crisis of 2008.

London goldsmith-bankers magically transformed their paper debts into money by exploiting the hybridity between sales and loans. In the second half of the seventeenth century, the common law, like continental law, clearly distinguished between a sale and a debt contract. To establish the rule of endorsements for the negotiability of bills of exchange, common law courts regarded a transfer of debt instruments 
without endorsement as a plain sale rather than a debt contract. ${ }^{10}$ Thus, unless debt instruments were endorsed by the transferor, transferees could not sue the transferor. Goldsmith-bankers exploited a loophole in this common law distinction: because the bankers' notes used a bearer clause that required a payer to pay anyone who held them and did not necessarily require endorsement for transfer, their transferors were no longer legally liable for the notes (Quinn, 2004, p 154). Exploiting this loophole, goldsmith-bankers' notes, mere credit instruments, became like money (Kim, 2011).

The hybrid, double ownership of shadow banking was enhanced when many institutional investment funds were organised as trusts rather than corporations. According to Langbein (1997), in 1997 half of all mutual funds were in trusts. Funds choose the trust form because it offers them freedoms that are unavailable to corporations. For example, the investment trust can avoid the internal governance structure that state corporation statutes impose on corporations. Furthermore, the trust form allows MMMFs to create and extinguish trust shares and thus be open-ended. In contrast, corporations need shareholders' approval to increase the maximum number of shares authorised in the corporations' certificate of incorporation. Asset securitisation trusts also take the trust form because it gives them the freedom to carve shares into tranches, a freedom that corporations do not have (Langbein, 1997, p 183). These freedoms of the investment trust - the freedom to tailor interests flexibly, and freedom from regulatory governance mechanisms - reflect, as Langbein argues (1997, p 184), the root principle of the early trust, which was to give property owners absolute freedom over their property. The investment trusts have the freedom to structure their organisational regimes in any way they wish to preserve and enhance private property ownership (Langbein, 1997, p 184).

Before capitalism - especially in the Roman and civil law traditions - the rights and responsibilities of creditors were clearly distinct from those of owners. Owners could control ownership but had to take responsibility for the use of their property. By contrast, creditors took an interest in but did not take any responsibility for how their debtors used their property. But by exploiting hybridity, shareholders and depositors can enjoy the rights of debtors and the rights of owners whilst minimising their responsibility as owners. The depositors can receive safekeeping services from modern bankers without paying safekeeping fees and furthermore earn interest without being responsible for the bankers' use of deposits. The shareholders are the owners of a company, so the company is obliged to promote the interest of the shareholders. But they are simultaneously hidden behind the company's professional managers and avoid legal responsibility for the use of the money they have invested in the company. The shareholders accept only a limited liability when the company goes bankrupt, just as creditors lose only their loaned money when a debtor goes bankrupt. The depositors of modern banking and the shareholders of the open-ended trust fund get an interest-like income even though they do not cede the present availability and ownership of their money. The creation of money out of thin air by modern banking is, as the Austrian economists have demonstrated persuasively, a fraud. This use of a trust in modern finance also gives birth to big institutional debtors who can enjoy the benefit of permanent indebtedness. As mentioned earlier, the permanent indebtedness of modern banks transforms a portion of their debts into permanent capital that the banks do not need to repay and can use for personal gain.

${ }^{10}$ Bank of England v. Newman (1700), 1 Ld. Raym. 442. 


\section{Conclusion: forgiveness}

So far, we have examined how the hybrid, double ownership scheme has been used in modern finance and how modern finance began as a project to prolong the endurance of the modern relationship of person-property. I finish this article by commenting briefly on one of the moral implications of the project-forgiveness. This comment is speculative and incomplete, but it offers a direction for future research. Let us begin by looking briefly at Keynes's psychological economics.

A financial investor, for Keynes, is a 'purposive' man who is 'always trying to secure a spurious and delusive immortality for his acts by pushing his interest in them forward into time' (Keynes, 1972, pp 9:329-30). This tendency constitutes the essence of Keynes's theory of money and his main theoretical categories, such as uncertainty, hoarding propensity, liquidity preference and interest rates. The more pre-occupied an investor is with the remote future of his actions and being, the more anxiety about the uncertain future haunts his mode of behaviour. This anxiety, according to Keynes, is alleviated through the possession of money, which thus explains why a purposive man has a morbid 'hoarding propensity' and 'liquidity preference' (Keynes, 1972, pp 14:115-16). This anxiety also constitutes the essence of Keynes's theory of interest rates and differentiates it from the classical theory of interest rates. In classical theory, the rate of interest falls when the quantity of money increases. Keynes found, however, that the rate does not fall as the quantity increases, because some quantity of money disappears into the hands of money-holders for their precautionary and speculative motives, that is, because a psychological tendency to hoard money in the form of liquidity easily offsets the increase in the quantity of money. When, during a crisis, liquidity preference and hoarding propensity increase sharply, Keynes found that an increase in the rate of interest plays a role in 'being the inducement not to hoard'. Thus, he defined the rate of interest as 'the measure of the degree of our disquietude' - that is, the degree of our anxiety over the uncertain future (1972, p 14:110).

Keynes's economic psychology of temporality or of the uncertain future is, arguably, specific to a society that has a specific attitude towards time. Societies have struggled to cancel the temporality that causes ontological suffering and fear. According to Eliade (1954), there are three anti-temporal conceptions aiming to abolish the irreversibility of time. The first is the conception of an eternal present, in which the past and the future are not facts that belong to different moments of time. Its example is the Buddhist conception of time.

The second is the primitive cyclic conception of time, which abolishes time and history an infinite number of times, 'by means of periodically repeated ritual (for example, the rites for the beginning of the year)'. Many ancient communities with this cyclic conception of time held a communal ritual of forgiving all the sins that community members committed during the previous year. This forgiveness could be regarded as both the destruction of the previous self and the birth of a new self, because forgiveness is possible when all past happenings are abolished. In these communities, the self was conceptualised as circular: it was destroyed and born anew every year (Eliade, 1954). The cyclic abolition of the self accompanied a cyclic abolition of debt as well. ${ }^{11}$ Throughout history, indebtedness has often been regarded as equivalent to guilt. Thus, in Babylonian, Sumerian and other civilisations, debts were cancelled by the emperor

${ }^{11}$ In nearly all languages, the word debt is synonymous with the word sin or guilt (Graeber, 2011). 
in a periodic 'redemption' or 'year of jubilation', and when a king or queen succeeded to the throne, he or she cancelled both the debt accrued by the previous kings and the debts that ordinary people owed to tax farmers (Graeber, 2011, pp 64-65, 81-87). As Eliade (1954, p 144) argues, this cyclic conception of time had been popular until as late as the seventeenth century.

The third anti-temporal conception is the modern conception of Christian eschatological or messianic time, which abolishes time and history only once in the unforeseeable future at the end of world, in which the dead are resurrected and eternity wins the victory against time. In the modern world, Christian time has been secularised. This secularised time is no longer anti-temporal: time is never abolished. Secularised time is a mode of the modern self. Like modern secularised time, the modern self is no longer abolished. The era in which secularised historical time dominates corresponds with the era in which the modern credit economy dominates.

The communal cancellation of debt is now replaced by periodic economic crises, when modern society no longer periodically forgives debtors through peaceful communal events. In modern times, as Locke argued, the idea of personal identity is the basis for considering reward and punishment to be justified. Because the idea of personal identity assumes the continuity and preservation of the self, this continuity accumulates all past happenings, including sinful acts, and prevents any salvation before the end of the continuity (Eliade, 1954). As long as the modern money economy is based on the idea of identity, guilt and the past are inexpiable, and debts are not forgiven. Thus, English law in the early modern era strictly punished the bankrupt. However, since the hybridity of modern finance has led to the growth of the big modern debtors, there have been two competing views on the forgiveness of debtors. Big institutional financial firms impose strict obligations for repayment on their debtors, but when a financial crisis occurs, these big institutional debtors ask their governments for bailouts at the taxpayers' expense. As soon as taxpayers' money is paid for bailouts, the fictionally created money of the banks becomes real money, cash. Every community needs the communal cancellations of guilt and debt, but in modern times, the communal cancellation of these big debtors' debts is no longer ethical, because these debtors have benefitted privately at the cost of the destiny of the community. For the past few centuries, societies have struggled between two possible ways to remedy financial crises. The first way is to forgive these big debtors and let them make a fresh start; the other is to let financial crises forcefully clear untrustworthy debts, not only expelling big debtors from business but also generating high costs for third parties who are innocently involved in the transactions of modern banking, including workers and consumers.

Recognising the hybridity of modern finance is important for a program for financial reform through which the communal cancellation of guilt and debt becomes ethical. A general reform principle that we can suggest is the abolition of hybridity. That is, a reform should create a clear distinction between all investors' rights as rights in rem or rights in personam, rather than allow these two rights to be mixed. Creating such a distinction would require the abolition of the fractional-reserve scheme of commercial banks and the open-ended schemes of investment funds and repos. This reform principle is simple, requires minimal governmental intervention in the economy and does not necessitate the creation of a bureaucratic governmental apparatus.

This reform principle can said to be general because it can also be applied to corporate reform policy, since the joint stock arrangement with limited liability in business corporations is also a trust. In this sense, my research fits with the research of critical 


\section{J. Kim}

legal theorist Paddy Ireland. He has advocated for the abolition of the hybridity of shareholders' rights - that is, for a radical reconceptualisation of shareholders as creditors (see Ireland, 2009). He believes that this reconceptualisation can abolish the neoliberal corporate governance model that is based on the ideology of shareholder value and has led corporations to neglect their social responsibility.

In the late Middle Ages, the West had already developed a more just form of finance than the modern hybrid form. The Bank of Amsterdam, a highly respected continental public bank during the seventeenth century, was established to abolish hybridity, that is, to clearly distinguish loan making and deposit taking, and thus it maintained a $100 \%$ reserve ratio for over 150 years after its foundation in 1609 (Huerta de Soto, 2009, p 99). Even with a full reserve, the bank supported trade. Merchants in Amsterdam were legally obliged to present their bills of exchange to the bank, where the debts of the bills were cleared amongst merchants. The financial role of public deposit banks on the continent was to clear the creditor-debtor relationships, whereas modern banking extends creditor-debtor relations.

To fully justify the public policy recommended here, at least the following two sets of problems of fractional-reserve banking must be addressed. The first is how this type of banking distorts the balanced distribution of resources amongst different industries and how the system creates banking crises and hurts innocent third parties. These problems have been explored deeply by the Austrian school of economists (see Huerta de Soto, 2009). The second is one of the major roles of modern banking since its inception. As mentioned, Kim (2011) demonstrates that the first modern bankers, goldsmith-bankers, arose because of the political struggle between the Crown and landowners in England. Kim (in press) further identifies that the Bank of England was established and developed through the strategic alliance that politicians made with financiers to collect money to wage international wars. He concludes that modern banking in early modern times was a war machine and that, because the English fractional-reserve system turned out to be more efficient in this regard than the continental European full-reserve system, the former has been the dominant form of modern banking since the nineteenth century.

This story seems to hold true for shadow banking in twentieth- and twenty-first century America. Since the 1970s, the government has needed to continue increasing its public debt, which it has needed to wage wars, including the Vietnam War, the Persian GulfWar, and the Iraq War. After the 1970s, however, commercial banks were no longer the main purchasers of US public debt. Since then, shadow banking has increasingly supported the growth of the US public debt. For example, mutual funds and MMMFs have invested heavily in public debt. The prime dealers in public debt finance their activities by using repurchase agreements that amounted to $\$ 4.2$ trillion in early 2008. Treasury bills and bonds are used as the main collateral in repurchase agreements. Shadow banking has needed the government's legal and political support to ensure that its money-like credit instruments are treated differently from other simple credit instruments. My future research project hypothesises that, since the early 1970s, the US government and shadow banking have mutually supported each other, and this mutual support has contributed to the boom of shadow-banking instruments.

There are some philosophical implications of the postmodern and Buddhist perspectives of the self for some of the topics that have been discussed in this article. First, these perspectives teach us not to be purposive: here 'purposive' is meant in the Keynesian sense implying a desire to secure 'a spurious and delusive immortality'. 
Capitalist accumulation and the propensity to hoard exist because people are ignorant of the fact that our true being exists at present where an enjoyable completeness of the universe is in full blossom. Buddhism has developed many mediation techniques and lessons that help us be conscious of the enjoyable completeness of the eternal present.

Second, in Roman law social relations were reduced to two different transactionsmoney transactions and loan transactions - or to two different rights — rights in rem and rights in personam. Roman law has significantly influenced modern law. This reduction of social relations, however, is unjustifiable from postmodern and Whiteheadian perspectives. A money transaction allows the payer to finally clear any obligations and connection to the payee. But this final clearance is ontologically impossible because his or her existence is an ensemble of social connections. Thus, money is an imaginary social device that allows what cannot be cleared to be cleared. Loan transactions are also ontologically unjustified. As mentioned, the cancellation of guilt and debt is the same process as the cancellation of the self. If we are conscious that the self is created and destroyed at every moment, we lose the fundamental ground for imposing strict debt obligations on debtors, because the present persons are no longer the previous debtors. If we accept the postmodern and Whiteheadian critiques of identity, we cannot reduce mutual connectedness and obligations to cold-blooded calculation because there is a definite yardstick for the calculation. This essay has examined how those two reduced social relations have become combined, and how this hybridity has unprecedentedly and permanently contributed to the power and identity of property owners. Thus, the abolition of this hybridity only gets us half-way to realising full social connectedness. This abolition merely prevents property owners from abusing their power.

\section{Bibliography}

Cotterrell, R. 1987. Power, property and the law of trusts, fournal of Law and Society, vol. 14, no. $1,77-90$

de Roover, R. 1974. Business, Banking, and Economic Thought in Late Medieval and Early Modern Europe, Chicago, University of Chicago Press

Eliade, M. 1954. The Myth of the Eternal Return, Princeton, Princeton University Press

Financial Crisis Inquiry Commission (FCIC). 2011. The Financial Crisis Inquiry Report, available at http://fcic.law.stanford.edu/report

Gorton, G. and Metrick, A. 2010. Regulating the shadow banking system, Brookings Papers on Economic Activity, 261-312

Graeber, D. 2011. Debt, New York, Melville House Publising

Hegel, G. W. 1962. Philosophy of Right, Oxford, Clarendon Press

Horsefield, J. K. 1977. The beginnings of paper money in England, fournal of European Economic History, vol. 6, no. 1, 117-33

Huerta de Soto, J. 2009. Money, Bank Credit, and Economic Cycles, Auburn, Ludwig Von Mises Institute

Ireland, P. 2009. Financialization and corporate governance, Northern Ireland Legal Quarterly, vol. 60 , no. $1,1-34$

Kacperczyk, M., and Schnabl, P. 2010. When safe proved risky: commercial paper during the financial crisis of 2007-2009, fournal of Economic Perspectives, vol. 24, no. 1, 29-50

Keynes, J. M. 1972. The Collected Writings of fohn Maynard Keynes, 30 vols., London, St. Martin's Press

Kim, J. 2011. How modern banking originated: the London goldsmith-bankers' institutionalisation of trust, Business History, vol. 53, no. 6, 939-59

Kim, J. In press. Modern Politics as a Trust Scheme, and its Relevance to Modern Banking, Fournal of Economic Issues

Langbein, J. H. 1997. The secret life of the trust, Yale Law Fournal, vol. 107, 165-89 
Locke, J. 1690 [1988]. Two Treatises of Government, Cambridge, Cambridge University Press

Macfarlane, A. 1973. The Origins of English Individualism, Oxford, Blackwell

Macfarlane, A. 2002. The Making of the Modern World, New York, Palgrave

Macpherson, C. B. 1975. Capitalism and the changing concept of property. In Feudalism, Capitalism and Beyond (pp. 104-25). London, Edward Arnold

Maitland, F. W. 1911. The Collected Papers of Frederic William Maitland (Vol. 3). Cambridge

Martin, J. E. 2001. Modern Equity. London, Sweet \& Maxwell

Mirowski, P. 1989. More Heat than Light:Economics as Social Physics, Physics as Nature's Economics. Cambridge: Cambridge University Press

Musto, D. K. 2011. The Economics of Mutual Funds, The Annual Review of Financial Economics, vol. 3, 159-72.

Neale, R. S. 1975. The bourgeoisie, historically, has played a most revolutionary part, pp. 84103 in Feudalism, Capitalism and Beyond, London, Edward Arnold

Nietssche, F. W. 1989. On the Genealogy of Morality. Toronto, Random House of Canada

Pipes, R. 2000. Property and Freedom, Toronto, Random House of Canada

Quinn, S. F. 2004. Money, finance and capital markets, pp. 1:147-74 in The Cambridge Economic History of Modern Britain, Cambridge, Cambridge University Press

Rogers, J. S. 1995. The Early History of the Law of Bills and Notes, Cambridge, Cambridge University Press

Rubin, G. R., and Sugarman, D. 1984. Introduction, pp. 1-123 in Law, Economy and Society, 1750-1914, Oxford, Professional Books

Simmel, G. 1896 [1991]. Money in modern culture, Theory, Culture E Society, vol. 8, 17-31

Stein, J. C. 2005. Why are most funds open-end?, Quarterly fournal of Economics, vol. 120, no. $1,247-72$

Temin, P., and Voth, H.-J. 2006. Banking as an emerging technology: Hoare's Bank, 1702-1742, Financial History Review, vol. 13, no. 2, 149-78

White, L. H. 2003. Accounting for fractional-reserve banknotes and deposits, Independent Review, vol. 7, no. 3, 423-41

Whitehead, A. N. 1978. Process and Reality, New York, Free Press 